\title{
Povezanost zadovoljstva nastavom metodike likovne kulture s nekim aspektima obveza studenata i organizacije nastave
}

\author{
Marijana Županić Benić* \\ marijana.zbenic@ufzg.hr
}

UDK: $378.637(497.5)$

$7: 371.3$

Prethodno priopćenje / Preliminary communication Primljeno: 24. siječnja 2017. Prihvaćeno: 9. svibnja 2017.

U radu je istražena povezanost između zadovoljstva nastavom iz metodike likovne kulture (MLK) s organizacijom nastave i obvezama studenata. Izdvojeni su samo neki od aspekata organizacije nastave koji u kontekstu ovog istraživanja podrazumijevaju broj studenata na predavanjima $i$ vježbama, a obveze studenata vezane uz studij mjere se brojem izostanaka $i$ njihovim završnim ocjenama. Istraživanje je provedeno na sedam učiteljskih fakulteta u Republici Hrvatskoj na uzorku od 220 studenata treće godine Ranog i predškolskog odgoja i obrazovanja. Korelacije su provedene na nezavisnim varijablama završna ocjena, broj izostanaka, broj studenata na predavanjima $i$ vježbama iz MLK $i$ tvrdnji vezanih uz skupne zavisne varijable, od kojih su u statistički značajnoj korelaciji: nastavno posredovanje, praćenje i ocjenjivanje studenata $i$ organizacija nastave MLK. Zadovoljstvo studenata nastavom iz MLK u ovom istraživanju najviše je izraženo putem korelacija nezavisnih varijabli s nastavnim posredovanjem koje podrazumijeva kvalitetnu nastavnikovu izvedbu nastave $i$ suradnički odnos sa studentima. Kao i kod prethodnih istraživanja, veće zadovoljstvo studenata povezano je s radom u manjim skupinama, a i s manjim brojem izostanaka s nastave.

Ključne riječi: zadovoljstvo nastavom, metodika likovne kulture, obveze studenata, organizacija nastave.

\footnotetext{
* Dr. sc. Marijana Županić Benić, predavačica na Učiteljskom fakultetu Sveučilišta u Zagrebu; Savska c. 77, HR-10000 Zagreb.
} 


\section{Uvod}

Proučavanjem zadovoljstva studenata nastavom utvrđeno je da cjelokupno zadovoljstvo studenata može ovisiti o sljedećim aspektima nastave: nastavno posredovanje, metodičko posredovanje, praćenje i ocjenjivanje rada studenata, karakteristike organizacije nastavnog predmeta, dostupnost nastavnih materijala i sredstava te razini kompetentnosti za djelovanje koju su studenti stekli kroz predmet i studij. ${ }^{1}$ Nastavno posredovanje odnosi se na sposobnosti nastavnika da uspostave pozitivne odnose sa studentima kao preduvjet za suradnju u procesu učenje te da efektivno prenose teorijska znanja i praktična iskustva koristeći primjerene nastavne metode, što zahtijeva adekvatnu razinu nastavnih umijeća s njihove strane. ${ }^{2}$ Metodičko posredovanje odnosi se na sposobnost mentora da pripreme studente za metodičko djelovanje putem metodičkih vježbi, koje se moraju odvijati u suradničkom odnosu sa studentima što im omogućava aktivno sudjelovanje u nastavnom procesu.

Dio organizacije nastavnog predmeta, pa time i metodike likovne kulture (MLK) i vrlo važan čimbenik kvalitete nastave jest određivanje broja studenata na nastavi. Predavanja su obično organizirana za sve studente na godini, a veći broj studenata na nastavi podrazumijeva i slabiju kvalitetu u odnosu na rad $\mathrm{u}$ manjim skupinama, primjerice na vježbama. Manji broj studenata u skupini omogućuje i nastavnicima i studentima da svoje odnose temelje na suradničkom odnosu koji doprinosi boljoj komunikaciji, interakciji i većoj aktivnosti studenata na nastavi. Redovito pohađanje nastave te priprema i izlazak na završni ispit ključne su obveze studenata koje bi mogle biti povezane s njihovim zadovoljstvom.

Velike skupine na predavanjima negativno utječu na kvalitetu nastave jer umanjuju kvalitetu razrednoga ozračja, a to se događa zato što se prilikom višeminutnih izlaganja ( 90 minuta) u velikim amfiteatrima ograničavaju biološke potrebe (npr. kretanje, svjež zrak) i socijalne potrebe (npr. potreba za su-

\footnotetext{
${ }^{1}$ Susana CAIRES, Leandro ALMEIDA, Diana VIEIRA, Becoming a teacher: Student teacher's experiences and perceptions about teaching practice, European Journal of Teacher Education, 35 (2012) 2, 163-178; Anthony G. GREENWALD, Gerald M. GILLMORE, No pain, no gain? The importance of measuring course workload in student ratings of instruction, Journal of Educational Psychology, 89 (1997) 4, 743-751; Neven RICIJAŠ, Aleksandra HUIĆ, Vanja BRANICA, Zadovoljstvo studijem i samoprocjena kompetentnosti studenata nekih pomagačkih profesija, Hrvatska revija za rehabilitacijska istraživanja, 42 (2006) 2, 51-68; Frank D. TALLMAN, Satisfaction and completion in correspondence study: The influence of instructional and student-support services, American Journal of Distance Education, 8 (1994) 2, 43-57; Tihomir VRANESEEVIĆ, Miroslav MANDIĆ, Sandra HORVAT, Istraživanje činitelja zadovoljstva nastavom, Poslovna izvrsnost - znanstveni časopis za promicanje kulture kvalitete i poslovne izvrsnosti, 1 (2007) 1, 83-92.

${ }^{2}$ Chris KYRIACOU, Temeljna nastavna umijeća. Metodički priručnik za uspješno poučavanje $i$ učenje, Zagreb, Educa, 1995, 127.
} 
radnjom) studenata. ${ }^{3}$ Isto tako ističu da je »u frontalnoj predavačkoj nastavi u velikim skupinama smanjena mogućnost osobne afirmacije i samoaktualizacije jer su studenti anonimni sudionici mase ${ }^{4}{ }^{4}$

U dosadašnjim istraživanjima ističe se podatak da postoji slaba negativna povezanost između veličina skupina na fakultetu i cjelokupnog zadovoljstva studenata predavanjima te njihova zadovoljstva kvalitetom izlaganja nastavnog sadržaja, a potvrđena je i snažna negativna povezanost između veličine skupina na predavanjima i zadovoljstva odnosa studenata s nastavnicima. ${ }^{5} \mathrm{~S}$ obzirom na to da u većim skupinama najviše slabi zadovoljstvo studenata odnosom $\mathrm{s}$ nastavnicima i interakcijom nastavnika sa studentima, može se reći da je teško uspostaviti odnos nastavnika i studenata koji se temelji na interakciji onda kada nastavnik mora raditi s mnogo studenata istovremeno.

Osim što kod organizacije nastave nekog predmeta na fakultetu previše studenata na predavanjima i vježbama može biti negativno povezano s njihovim zadovoljstvom nastavom, veličina skupina na fakultetu povezana je i s ozbiljnijim problemima. Bettinger i Long istražili su povezanost veličina skupina studenata na fakultetu s ishodima obrazovanja, a rezultati su ukazali na to da veće skupine na teorijskim predavanjima i vježbama, odnosno praktičnim satima, povećavaju vjerojatnost ispisivanja studenata s fakulteta te uzrokuju dulje studiranje. ${ }^{6}$ Mjerenjem zadovoljstva studenata nastavom u poslovnim visokoškolskim ustanovama utvrđeno je da su nastavnici i organizacija predmeta najznačajniji prediktori razvoja kompetencija studenata i njihove pripremljenosti za obavljanje buduće djelatnosti, a veličina skupina na predavanjima bila je jedna od značajnih karakteristika organizacije predmeta.?

Pohađanje nastave jedan je od prediktora završnih ocjena studenata, a studenti s manjim brojem izostanaka imaju veće završne ocjene. ${ }^{8}$ Utvrđeno je da je pohađanje nastave i najvažniji prediktor završne ocjene kada se usporedi s ostalim prediktorima, poput ocjena iz srednje škole i motivacijom studenata. ${ }^{9}$ Pretpostavlja se da redovito pohađanje nastave omogućava studentima da nau-

${ }^{3}$ Ladislav BOGNAR, Snježana KRAGULJ, Kvaliteta nastave na fakultetu, Život $i$ škola - časopis za teoriju i praksu odgoja i obrazovanja, 56 (2010) 24, 169-182.

${ }^{4}$ Isto, 179.

${ }^{5}$ Kenneth A. FELDMAN, Class size and college students' evaluations of teachers and courses: A closer look, Research in Higher Education, 21 (1984) 1, 45-116.

${ }^{6}$ Eric P. BETTINGER, Bridget Terry LONG, Mass Instruction or Higher Learning? The Impact of College Class Size on Student Retention and Graduation, Education Finance and Policy, 0 (2016) ja, 1-36.

7 Allen GIBSON, Measuring business student satisfaction. A review and summary of the major predictors, Journal of Higher Education Policy and Management, 32 (2010) 3, 251-259.

${ }_{8}$ M. Victoria LÓPEZ-PÉREZ, M. Carmen PÉREZ-LÓPEZ, Lázaro RODRÍGUEZ-ARIZA, Blended learning in higher education. Students' perceptions and their relation to outcomes, Computers \& Education, 56 (2011) 3, 818-826.

9 Marcus CREDÉ, Sylvia G. ROCH, Urszula M. KIESZCZYNKA, Class attendance in college a meta-analytic review of the relationship of class attendance with grades and student characteristics, Review of Educational Research, 80 (2010) 2, 272-295. 
če one sadržaje koji im nisu dostupni u udžbenicima i da prisustvuju različitim oblicima nastave, uključujući predavanja, demonstracije, vježbe i ostale oblike nastave. Čak i pasivno prisustvovanje nastavi može se pozitivno odraziti na kompetencije studenata i njihove završne ocjene. ${ }^{10}$

Potvrđena je i povezanost pohađanja nastave s motivacijom i zadovoljstvom studenata, što može značiti da i osobne karakteristike studenata i kompetencije nastavnika mogu djelovati na redovito pohađanje nastave. ${ }^{11}$ Interes za pojedino područje, što bi u slučaju predmeta MLK bila likovna umjetnost, primjer je osobne motivacije koja bi mogla utjecati na njihov interes za sudjelovanje na nastavi i pohađanje predavanja. Na primjer, postoji mogućnost da studenti koji nisu motivirani za studij ili koji imaju niske sposobnosti samoregulacije ponašanja, izostaju s predavanja neovisno o kvaliteti nastave. ${ }^{12}$ Pokazalo se i da važnost koju studenti pridaju pohađanju predavanja pozitivno utječe na njihov stvarni broj dolazaka na nastavu. ${ }^{13}$

Nastavnik može djelovati i na motivaciju studenata i na njihovo zadovoljstvo predavanjima, što se u tom slučaju pozitivno odražava na njihovo redovito pohađanje nastave. Implementacija informacijske tehnologije radi poticanja aktivnog sudjelovanja studenata u nastavi može smanjiti broj izostanaka studenata s $25 \%$ na $0-2 \%{ }^{14}$ Dakle, nastavnici bi trebali aktivno poticati sudjelovanje studenata na nastavi da bi smanjili broj izostanaka na predmetu, ali bez tehnoloških pomagala takvu je nastavu teško voditi u velikim skupinama. Frontalna nastava u skupinama mogla bi se nadopuniti individualnim i skupnim zadacima koji se mogu provoditi neovisno o broju studenata. ${ }^{15}$ Ako su zadaci primjereni sadržaju koji se izlaže na predavanju, studenti će biti uključeni u nastavu, što bi se trebalo pozitivno odraziti na njihovu motivaciju za pohađanjem nastave.

Rad u manjim skupinama i manji broj izostanaka povezani su s većim zadovoljstvom studenata. ${ }^{16}$ Pretpostavlja se da je veličina skupina važna za akademska postignuća studenata i njihovo zadovoljstvo nastavom jer se u manjim skupinama može ostvariti kvalitetnija interakcija i suradnja s nastavnicima, a u većim skupinama studenti uglavnom pasivno slušaju predavanja i u masi gube osjećaj individualnosti.

\footnotetext{
${ }^{10}$ Isto, 272-295.

${ }^{11}$ López-Pérez, Pérez-López, Rodriguez-Ariza, nav. dj., 818-826.

${ }^{12}$ Credé, Roch, Kieszczynka, nav. dj., 272-295.

${ }^{13}$ Steven E. GUMP, Guess who's (not) coming to class. Student attitudes as indicators of attendance, Educational Studies, 32 (2006) 1, 39-46.

${ }^{14}$ Isto, 21.

${ }^{15}$ Bognar, Kragulj, nav. dj., 169-182.

${ }^{16}$ Shaun Michael BURNS, Larry LUDLOW, Understanding student evaluations of teaching quality. The contributions of class attendance, Journal of Personnel Evaluation in Education, 18 (2005) 2, 127-138.
} 


\section{Metodologija istraživanja}

\subsection{Uzorak ispitanika i instrument mjerenja}

U empirijskom istraživanju sudjelovalo je ukupno 220 sudionika. Riječ je o namjernom uzorku jer su uključeni svi studenti treće godine Ranog i predškolskog odgoja koji su odslušali i položili ispit iz nastavnog predmeta MLK. Istraživanjem su obuhvaćeni svi učiteljski fakulteti s izuzetkom Fakulteta za odgojne i obrazovne znanosti u Osijeku. Istraživanje je provedeno u ljetnom semestru ak. god. 2015./16.

Pregledom informacija o sudionicima prema općim obilježjima, $u$ istraživanju su sudjelovale uglavnom studentice $(99,1 \%)$ i to u dobi od $21(54,5 \%)$ ili 22 $(26,4 \%)$ godine. U istraživanje su uključeni: UF Zagreb (32,3\%), s dislociranim odsjecima UF Čakovec (6,8 \%) i UF Petrinja (9,1 \%); UF Rijeka (12,3 \%); UF Pula (16,4\%); UF Zadar (10 \%); UF Split (13,2\%).

Prema obilježjima vezanim uz studij, trećina studenata $(32,1 \%)$ završava Učiteljski fakultet u Zagrebu te između 6,8 \% i 16,4 \% ostale Učiteljske fakultete (u Puli, Splitu, Čakovcu, Petrinji, Rijeci i Zadru). Završnu ocjenu odličan iz MLK dobilo je 73,1 \% studenata u zadnjem semestru, a njih 22,7 \% dobilo je ocjenu vrlo dobar. Studenti su uglavnom redovito polazili nastavu iz MLK; $40,9 \%$ kaže da su s predavanja i vježbi izostali dva, tri puta, $32,3 \%$ da su izostali jednom i 22,3 \% da nisu izostali ni jedanput.

Anketni upitnik korišten u ovome istraživanju modificirana je verzija upitnika National Student Survey 2014. Questionnaire. ${ }^{17}$ Za potrebe pisanja ovog rada, izdvojene su varijable koje su usko vezane uz cilj i probleme istraživanja, a razvrstane su prema: općim obilježjima studenata (dob, spol) te obrazovnim obilježjima (naziv studija, završna ocjena, redovitost pohađanja nastave). Upitnik je sadržavao i varijable »broj studenata na predavanjima « (do 49, 50-99, 100 i više) i »broj studenata na vježbama na fakultetu i u vrtiću« (5-7, 8-15, 16-25) koje su mjerene kao kategorijalne varijable. Korištena su otvorena pitanja, pitanja dvostrukog i višestrukog izbora. Zatim su se Likertovom skalom propitivale varijable koje mjere zadovoljstvo studenata nastavom. Skala daje studentima mogućnost pet odgovora od "potpuno se slažem« do »uopće se ne slažem«. Odgovori nisu bili obilježeni numeričkim vrijednostima u anketi.

\footnotetext{
${ }^{17}$ HIGHER EDUCATION FUNDING COUNCIL FOR ENGLAND, National Student Survey 2014 Questionnaire, www.thestudentsurvey.com/content/NSS2015_Questionnaire.pdf (23.06.2016).
} 


\subsection{Cilj i problemi istraživanja}

Cilj ovog istraživanja bio je utvrđivanje povezanosti između zadovoljstva studenata nastavom MLK i organizacijom nastave te obvezama studenata. Organizacija nastave $u$ kontekstu ovog istraživanja podrazumijeva broj studenata na predavanjima i vježbama, a obveze studenata vezane su uz pohađanje nastave i izlazak na završni ispit pa se mjere brojem izostanaka i njihovim završnim ocjenama. S obzirom na cilj istraživanja, postavljeni su sljedeći problemi:

1. Istražiti povezanost zadovoljstva studenata nastavnim predmetom MLK sa završnom ocjenom zadnjeg semestra iz MLK.

2. Istražiti povezanost zadovoljstva studenata nastavnim predmetom MLK s brojem izostanaka s nastave.

3. Istražiti povezanost zadovoljstva studenata nastavnim predmetom MLK $\mathrm{s}$ brojem studenata na predavanjima i vježbama iz MLK.

\section{Rezultati}

Tablica 1. Rezultati Spearmanova koeficijenta korelacije izmedu nezavisnih varijabli i skupnih zavisnih varijabli

\begin{tabular}{|c|c|c|c|c|}
\hline VARIJABLA & 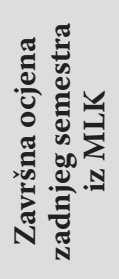 & 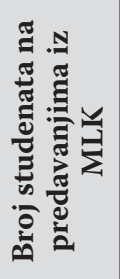 & 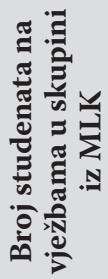 & 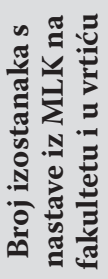 \\
\hline Nastavno posredovanje & $0,30^{\text {**\% }}$ & $0,13^{*}$ & $-0,01$ & $-0,15^{*}$ \\
\hline Praćenje i ocjenjivanje studenata & $0,24^{* * *}$ & 0,10 & 0,05 & $-0,03$ \\
\hline Metodičko posredovanje u školi/vrtiću & 0,05 & 0,00 & $0,16^{*}$ & 0,02 \\
\hline Organizacija nastave MLK & 0,10 & $-0,04$ & $0,17^{* * * *}$ & $-0,03$ \\
\hline Nastavna odgojno-obrazovna sredstva i pomagala & $-0,13$ & 0,04 & 0,03 & $-0,08$ \\
\hline Kompetencije studenata & 0,04 & $-0,09$ & $0,14^{*}$ & 0,09 \\
\hline
\end{tabular}

LEGENDA:

$\mathrm{R}$ - Spearmanov neparametrijski koeficijent korelacije

$\mathrm{p}$ - vjerojatnost pogreške

* - statistički značajna razlika uz $5 \%$ rizika

** - statistički značajna razlika uz $1 \%$ rizika

Rezultati Spearmanove korelacije između nezavisnih varijabli i skupnih zavisnih varijabli prikazani su u tablici 1 . Završna ocjena studenata bila je statistički značajno i pozitivno povezana sa skupnim varijablama »Nastavno posredovanje $\ll(r=0,30 ; p<0,01)$ i »Praćenje i ocjenjivanje studenata $(r=0,24$; 
$\mathrm{p}<0,01)$. Broj studenata na predavanjima iz MLK bio je statistički značajno i pozitivno povezan sa skupnom varijablom »Nastavno posredovanje« $(\mathrm{r}=0,13$; $\mathrm{p}<0,05)$. Broj studenata na vježbama u skupini iz MLK bio je statistički značajno i pozitivno povezan sa sljedećim skupnim varijablama: »Metodičko posredovanje u školi/vrtiću « $(\mathrm{r}=0,16 ; \mathrm{p}<0,05)$, »Organizacija nastave $M L K$ « $(\mathrm{r}=0,17$; $\mathrm{p}<0,01) \mathrm{i} »$ Kompetencije studenata $(\mathrm{r}=0,14 ; \mathrm{p}<0,05)$. Broj izostanaka studenata $\mathrm{s}$ nastave bio je statistički značajno i negativno povezan sa skupnom varijablom $»$ Nastavno posredovanje $\ll(r=-0,15 ; \mathrm{p}<0,05)$.

Tablica 2. Rezultati Spearmanova koeficijenta korelacije izmedu nezavisnih varijabli $i$ tvrdnji vezanih uz skupnu varijablu Nastavno posredovanje

\begin{tabular}{|c|c|c|c|c|}
\hline Varijabla & 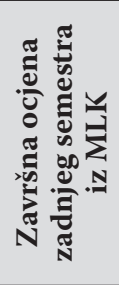 & 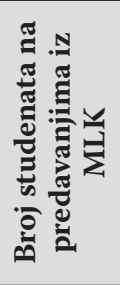 & 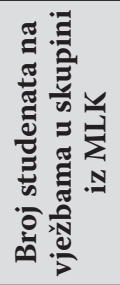 & 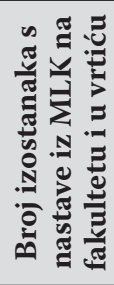 \\
\hline $\begin{array}{l}\text { Jasnoća i izlaganja i objašnjavanja sadržaja predmeta } \\
\text { MLK }\end{array}$ & $0,24^{* * *}$ & $0,17^{* * *}$ & $-0,09$ & $-0,20^{* * *}$ \\
\hline Usvojenost primjenjivih znanja i razumljivost iz MLK & $0,23^{* * *}$ & 0,12 & $-0,06$ & $-0,21^{* *}$ \\
\hline Jasnoća ishoda nastavnog predmeta MLK & 0,13 & 0,03 & $-0,02$ & $-0,14^{*}$ \\
\hline $\begin{array}{l}\text { Upotpunjenost nastavnih predavanja iz MLK na } \\
\text { fakultetu s primjerima nastavnikovih vlastitih } \\
\text { iskustava iz prakse }\end{array}$ & $0,32^{* * *}$ & 0,12 & 0,07 & $-0,12$ \\
\hline $\begin{array}{l}\text { Zanimljivost sadržaja nastavnih predavanja iz MLK na } \\
\text { fakultetu }\end{array}$ & $0,28^{* * *}$ & $0,16^{*}$ & $-0,03$ & $-0,16^{*}$ \\
\hline $\begin{array}{l}\text { Prepoznavanje i zadovoljavanje studentskih potreba } \\
\text { za profesionalnim osposobljavanjem tijekom nastave } \\
\text { iz MLK }\end{array}$ & $0,20^{* * *}$ & 0,09 & 0,00 & $-0,08$ \\
\hline $\begin{array}{l}\text { Poticanje aktivnosti i kritičkog mišljenja studenta na } \\
\text { nastavi iz MLK }\end{array}$ & $0,17^{* * *}$ & 0,11 & 0,08 & $-0,03$ \\
\hline $\begin{array}{l}\text { Prihvaćanje studentovih ideja i originalnosti na } \\
\text { nastavi iz MLK }\end{array}$ & $0,25^{* * *}$ & 0,13 & 0,05 & $-0,03$ \\
\hline $\begin{array}{l}\text { Mogućnost povezivanja nastavnih principa rada u } \\
\text { MLK s drugim metodikama }\end{array}$ & 0,11 & $-0,04$ & $-0,01$ & 0,01 \\
\hline Rado polaženje nastavnog predmeta MLK & $0,25^{* * *}$ & $0,19^{* * *}$ & $-0,04$ & $-0,20^{* * *}$ \\
\hline
\end{tabular}

\section{LEGENDA:}

$\mathrm{R}$ - Spearmanov neparametrijski koeficijent korelacije

$\mathrm{p}-$ vjerojatnost pogreške

* - statistički značajna razlika uz $5 \%$ rizika

** - statistički značajna razlika uz $1 \%$ rizika

Završna ocjena studenata bila je statistički značajno povezana sa sljedećim tvrdnjama vezanim uz skupnu varijablu »Nastavno posredovanje«: »Jasnoća izlaganja i objašnjavanja sadržaja predmeta MLK« $(r=0,24 ; \mathrm{p}<0,01)$, »Usvoje- 
nost primjenjivih znanja i razumljivost iz $\operatorname{MLK} \lll(\mathrm{r}=0,23 ; \mathrm{p}<0,01)$, »Upotpunjenost nastavnih predavanja iz MLK na fakultetu s primjerima nastavnikovih vlastitih iskustava iz prakse« $(\mathrm{r}=0,32 ; \mathrm{p}<0,01)$, »Zanimljivost sadržaja nastavnih predavanja iz MLK na fakultetu« $(\mathrm{r}=0,28 ; \mathrm{p}<0,01)$, Prepoznavanje i zadovoljavanje studentskih potreba za profesionalnim osposobljavanjem tijekom nastave iz MLK« $(r=0,20 ; p<0,01)$, »Poticanje aktivnosti i kritičkog mišljenja studenta na nastavi iz MLK« $(\mathrm{r}=0,17 ; \mathrm{p}<0,01)$, »Prihvaćanje studentovih ideja i originalnosti na nastavi iz MLK« $(\mathrm{r}=0,25 ; \mathrm{p}<0,01)$ te $»$ Rado polaženje nastavnog predmeta MLK« $(r=0,25 ; \mathrm{p}<0,01)$. Povezanost s navedenim tvrdnjama bila je pozitivna.

Broj izostanaka s nastave iz MLK bio je statistički značajno povezan sa sljedećim varijablama: »Jasnoća i izlaganja i objašnjavanja sadržaja predmeta MLK« $(\mathrm{r}=-0,20 ; \mathrm{p}<0,01)$, »Usvojenost primjenjivih znanja i razumljivost iz MLK« ( $\mathrm{r}=-$ $0,21 ; \mathrm{p}<0,01)$, »Jasnoća ishoda nastavnog predmeta MLK« $(\mathrm{r}=-0,14 ; \mathrm{p}<0,05)$, »Zanimljivost sadržaja nastavnih predavanja iz MLK na fakultetu« $(\mathrm{r}=-0,16$; $\mathrm{p}<0,05) \mathrm{i} »$ Rado polaženje nastavnog predmeta MLK« $(\mathrm{r}=-0,20 ; \mathrm{p}<0,01)$. Svi koeficijenti korelacije bili su negativno povezani s navedenim tvrdnjama

Varijabla »Broj studenata na predavanjima iz MLK« je statistički značajno i pozitivno povezana s tvrdnjama »Jasnoća i izlaganja i objašnjavanja sadržaja predmeta MLK« $(\mathrm{r}=0,17 ; \mathrm{p}<0,01)$, »Zanimljivost sadržaja nastavnih predavanja iz MLK na fakultetu« $(\mathrm{r}=0,16 ; \mathrm{p}<0,05) \mathrm{i} »$ Rado polaženje nastavnog predmeta $\operatorname{MLK} \lll(\mathrm{r}=0,19 ; \mathrm{p}<0,01)$.

Tablica 3. Rezultati Spearmanova koeficijenta korelacije izmedu nezavisnih varijabli $i$ tvrdnji vezanih uz skupnu varijablu Praćenje i ocjenjivanje studenata

\begin{tabular}{|c|c|c|c|c|}
\hline Varijabla & 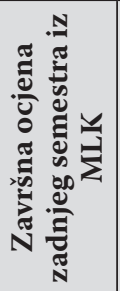 & 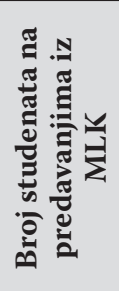 & 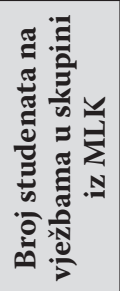 & 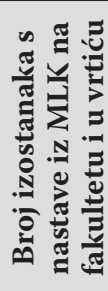 \\
\hline Jasnoća kriterija ocjenjivanja u MLK & 0,12 & 0,02 & 0,03 & 0,01 \\
\hline Objektivnost mojeg ocjenjivanja & $0,26^{\text {*** }}$ & 0,02 & 0,04 & $-0,03$ \\
\hline Mogućnost (pr)ocjenjivanja sebe i drugih & $0,17^{* * *}$ & 0,08 & 0,05 & $-0,05$ \\
\hline Dobivanje na vrijeme povratnih informacija o svom radu & $0,23^{* * *}$ & 0,11 & 0,04 & $-0,05$ \\
\hline $\begin{array}{l}\text { Konkretnost i jasnoća povratnih informacija nastavnika } \\
\text { o mojem radu }\end{array}$ & $0,28^{* * *}$ & 0,09 & $-0,04$ & 0,01 \\
\hline
\end{tabular}

LEGENDA:

$\mathrm{R}$ - Spearmanov neparametrijski koeficijent korelacije

$\mathrm{p}$ - vjerojatnost pogreške

* - statistički značajna razlika uz $5 \%$ rizika

*** - statistički značajna razlika uz $1 \%$ rizika 
Tvrdnje vezane uz skupnu varijablu »Praćenje i ocjenjivanje studenata« bile su statistički značajno povezane samo s varijablom »Završna ocjena zadnjeg semestra iz MLK" (tablica 3). Uočene su pozitivne korelacije između završne ocjene i sljedećih varijabli: »Objektivnost mojeg ocjenjivanja« $(r=0,26 ; p<0,01)$, »Mogućnost ( $\mathrm{pr}$ )ocjenjivanja sebe i drugih « $(\mathrm{r}=0,17 ; \mathrm{p}<0,01)$, »Dobivanje na vrijeme povratnih informacija o svom radu« $(r=0,23 ; p<0,01) i » K o n k r e t n o s t ~ i$ jasnoća povratnih informacija nastavnika o mojem radu« $(\mathrm{r}=0,28 ; \mathrm{p}<0,01)$.

Tablica 4. Rezultati Spearmanova koeficijenta korelacije izmedu nezavisnih varijabli i tvrdnji vezanih uz skupnu varijablu Metodičko posredovanje

\begin{tabular}{|c|c|c|c|c|}
\hline Varijabla & 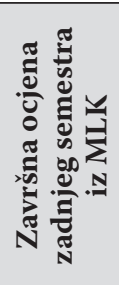 & 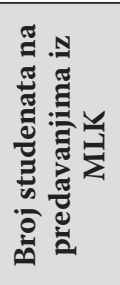 & 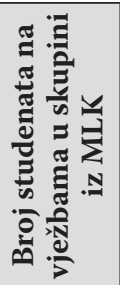 & 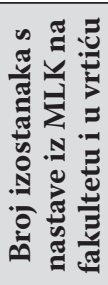 \\
\hline $\begin{array}{l}\text { Razumljivost stvari koje nisu bile jasne pomoću } \\
\text { povratnih informacija o mojem radu (izvedbi } \\
\text { aktivnosti u vrtiću iz MLK) }\end{array}$ & $0,16^{*}$ & 0,11 & 0,02 & $-0,05$ \\
\hline $\begin{array}{l}\text { Partner/stvo u radu s ostalim studentima, sveučilišnim } \\
\text { nastavnikom i odgajateljem mentorom }\end{array}$ & 0,10 & 0,06 & $0,17^{* * *}$ & $-0,11$ \\
\hline $\begin{array}{l}\text { Nazočnost sveučilišnog nastavnika na izvedbi s } \\
\text { djecom u vrtiću iz MLK }\end{array}$ & 0,03 & $-0,15^{*}$ & $0,16^{*}$ & $0,13^{*}$ \\
\hline $\begin{array}{l}\text { Mogućnost planiranja, pripremanja i izvođenja } \\
\text { aktivnosti u okviru metodičkih vježbi iz MLK prema } \\
\text { vlastitim idejama }\end{array}$ & 0,03 & 0,01 & $0,14^{*}$ & 0,04 \\
\hline $\begin{array}{l}\text { Uplitanje mentora odgajatelja tijekom aktivnosti iz } \\
\text { MLK u izvedbu studenta s djecom }\end{array}$ & $0,13^{*}$ & $-0,01$ & $-0,03$ & $-0,07$ \\
\hline $\begin{array}{l}\text { Dobivanje dobrog savjeta i podrške od nastavnika vezi } \\
\text { s pripremanjem i izvođenjem metodičkih vježbi iz } \\
\text { MLK u vrtiću kada je bilo potrebno }\end{array}$ & 0,13 & 0,06 & 0,05 & 0,02 \\
\hline $\begin{array}{l}\text { Dobivanje dobrog savjeta i podrške od odgajatelja } \\
\text { mentora vezi s pripremanjem i izvođenjem } \\
\text { metodičkih vježbi iz MLK u vrtiću kada je bilo } \\
\text { potrebno }\end{array}$ & $-0,05$ & 0,04 & 0,04 & 0,00 \\
\hline $\begin{array}{l}\text { Zadovoljstvo studenta pristupom odgajatelja mentora } \\
\text { u vrtiću pri osposobljavanju za rad s djecom }\end{array}$ & $-0,12$ & 0,03 & 0,04 & $-0,04$ \\
\hline
\end{tabular}

\section{LEGENDA:}

$\mathrm{R}$ - Spearmanov neparametrijski koeficijent korelacije

$\mathrm{p}$ - vjerojatnost pogreške

* - statistički značajna razlika uz $5 \%$ rizika

**: - statistički značajna razlika uz $1 \%$ rizika

Završna ocjena studenata statistički značajno i pozitivno je povezana s tvrdnjama »Razumljivost stvari koje nisu bile jasne pomoću povratnih informacija o mojem radu (izvedbi aktivnosti u vrtiću iz MLK)« $(r=0,16 ; p<0,05)$ i 
»Uplitanje mentora odgajatelja tijekom aktivnosti iz MLK u izvedbu studenta s djecom $\ll(r=0,13 ; p<0,05)$.

Varijabla »Broj studenata na predavanjima iz MLK« je statistički značajno i negativno $s$ tvrdnjom »Nazočnost sveučilišnog nastavnika na izvedbi s djecom u vrtiću iz MLK« $(r=-0,15 ; \mathrm{p}<0,05)$.

Varijabla »Broj studenata na vježbama u skupini iz MLK« je statistički značajno i pozitivno povezana s 10 varijabli: »Partner/stvo u radu s ostalim studentima, sveučilišnim nastavnikom i odgajateljem mentorom « $(r=0,17 ; p<0,01)$, »Nazočnost sveučilišnog nastavnika na izvedbi s djecom u vrtiću iz MLK« $(\mathrm{r}=0,16 ; \mathrm{p}<0,05)$, »Mogućnost planiranja, pripremanja i izvođenja aktivnosti $\mathrm{u}$ okviru metodičkih vježbi iz MLK prema vlastitim idejama« $(\mathrm{r}=0,14 ; \mathrm{p}<0,05)$.

Tablica 5. Rezultati Spearmanova koeficijenta korelacije između nezavisnih varijabli $i$ tvrdnji vezanih uz skupnu varijablu Organizacija nastave $M L K$

\begin{tabular}{|c|c|c|c|c|}
\hline Varijabla & 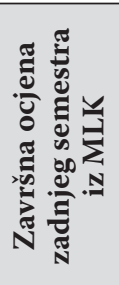 & 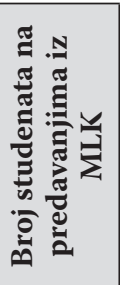 & 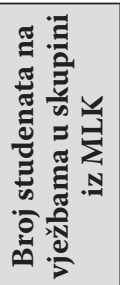 & 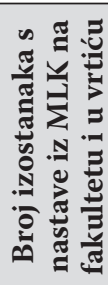 \\
\hline $\begin{array}{l}\text { Usklađenost rasporeda nastave na fakultetu i } \\
\text { rasporeda metodičkih vježbi iz MLK }\end{array}$ & 0,03 & $-0,09$ & $0,14^{*}$ & 0,04 \\
\hline $\begin{array}{l}\text { Pravovremeno i jasno priopćavanje promjena u } \\
\text { rasporedu i organizaciji metodičkih vježbi nastavnika }\end{array}$ & 0,10 & $-0,06$ & $0,20^{* * *}$ & $-0,04$ \\
\hline $\begin{array}{l}\text { Dobro organiziran rad u nastavi MLK odvijao se u } \\
\text { kontinuitetu i po silabusu }\end{array}$ & $0,17^{* * *}$ & 0,02 & 0,03 & $-0,08$ \\
\hline $\begin{array}{l}\text { Zastupljenost predavanja iz MLK tijekom studiranja } \\
\text { na fakultetu s dovoljnim brojem nastavnih sati }\end{array}$ & 0,08 & 0,02 & $0,21^{* * *}$ & $-0,07$ \\
\hline $\begin{array}{l}\text { Dovoljan broj nastavnih sati profesionalnog } \\
\text { osposobljavanja u vrtiću tijekom nastave MLK }\end{array}$ & 0,04 & 0,04 & 0,07 & 0,01 \\
\hline
\end{tabular}

LEGENDA:

$\mathrm{R}$ - Spearmanov neparametrijski koeficijent korelacije

$\mathrm{p}-$ vjerojatnost pogreške

* - statistički značajna razlika uz $5 \%$ rizika

** - statistički značajna razlika uz $1 \%$ rizika

Rezultati Spearmanove korelacije između nezavisnih varijabli i tvrdnji vezanih uz skupnu varijablu »Organizacija nastave MLK" prikazani su u tablici 5. Završna ocjena studenata bila je statistički značajno i pozitivno povezana s tvrdnjom »Dobro organiziran rad $u$ nastavi MLK odvijao se $u$ kontinuitetu i po silabusu « $(\mathrm{r}=0,17 ; \mathrm{p}<0,01)$.

Varijabla »Broj studenata na vježbama u skupini iz MLK« je statistički značajno i pozitivno povezana $s$ »Usklađenost rasporeda nastave na fakultetu i 
rasporeda metodičkih vježbi iz MLK« $(\mathrm{r}=0,14 ; \mathrm{p}<0,05)$, »Pravovremeno i jasno priopćavanje promjena u rasporedu i organizaciji metodičkih vježbi od strane nastavnika « $(\mathrm{r}=0,20 ; \mathrm{p}<0,01)$, »Zastupljenost predavanja iz MLK tijekom studiranja na fakultetu s dovoljnim brojem nastavnih sati« $(\mathrm{r}=0,21 ; \mathrm{p}<0,01)$.

Tablica 6. Rezultati Spearmanova koeficijenta korelacije izmedu nezavisnih varijabli $i$ tvrdnji vezanih uz skupnu varijablu Kompetencije studenata

\begin{tabular}{|c|c|c|c|c|}
\hline Varijabla & 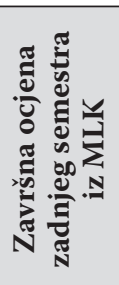 & 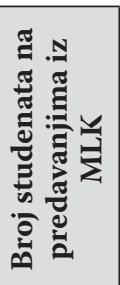 & 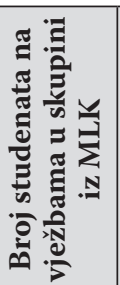 & 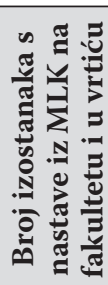 \\
\hline $\begin{array}{l}\text { Poticanje samopouzdanja u nastavi MLK u radu s } \\
\text { djecom }\end{array}$ & $0,17^{\text {*** }}$ & $-0,02$ & 0,02 & 0,09 \\
\hline $\begin{array}{l}\text { Poboljšanje komunikacijskih sposobnosti studenta } \\
\text { u radu s djecom u vrtiću nakon iskustva metodičkih } \\
\text { vježbi iz MLK }\end{array}$ & 0,09 & $-0,05$ & 0,06 & 0,06 \\
\hline $\begin{array}{l}\text { Stečenost kompetencija (znanja, vještina i } \\
\text { sposobnosti) kojima student može uspješno voditi } \\
\text { odgojno-obrazovni rad s djecom u vrtiću, nakon } \\
\text { položenog predmeta MLK }\end{array}$ & 0,09 & 0,08 & 0,04 & $-0,07$ \\
\hline $\begin{array}{l}\text { Poticanje razvoja socijalnih kompetencija (uspostava } \\
\text { kvalitetnog odnosa s djecom, mentorom odgajateljem, } \\
\text { sveučilišnim nastavnikom) metodičkim vježbama iz } \\
\text { MLK }\end{array}$ & 0,07 & $-0,07$ & $0,15^{*}$ & 0,08 \\
\hline $\begin{array}{l}\text { Važnost terenske nastave iz MLK u vrtiću za } \\
\text { profesionalno osposobljavanje studenata }\end{array}$ & $-0,02$ & $-0,14^{*}$ & 0,12 & 0,00 \\
\hline $\begin{array}{l}\text { Važnost terenske nastave iz MLK u muzejima i } \\
\text { galerijama za profesionalno osposobljavanje studenata }\end{array}$ & $-0,07$ & $-0,03$ & 0,09 & 0,12 \\
\hline $\begin{array}{l}\text { Sveukupno zadovoljstvo kvalitetom svojeg } \\
\text { osposobljavanja u MLK }\end{array}$ & 0,13 & 0,10 & 0,07 & $-0,09$ \\
\hline
\end{tabular}

\section{LEGENDA:}

$\mathrm{R}$ - Spearmanov neparametrijski koeficijent korelacije

$\mathrm{p}$ - vjerojatnost pogreške

* - statistički značajna razlika uz $5 \%$ rizika

** - statistički značajna razlika uz $1 \%$ rizika

Završna ocjena statistički značajno i pozitivno bila je povezana s tvrdnjom »Poticanje samopouzdanja u nastavi MLK u radu s djecom« $(\mathrm{r}=0,17 ; \mathrm{p}<0,01)$.

»Broj studenata na vježbama u skupini iz MLK« statistički značajno i pozitivno je povezan s tvrdnjom »Poticanje razvoja socijalnih kompetencija (uspostava kvalitetnog odnosa s djecom, mentorom odgajateljem, sveučilišnim nastavnikom) metodičkim vježbama iz MLK« $(\mathrm{r}=0,15 ; \mathrm{p}<0,05)$. 


\section{Rasprava}

Rezultati empirijskog istraživanja temelje se na utvrđivanju povezanosti između zadovoljstva studenata nastavom MLK i organizacije nastave te obvezama studenata.

Dobiveni rezultati utvrđivanja povezanosti pokazali su da postoje statistički značajne korelacije s obzirom na postavljene probleme.

Jedan od postavljenih problema bio je istražiti povezanost zadovoljstva studenata nastavnim predmetom MLK sa završnom ocjenom zadnjeg semestra iz $M L K$.

Prilikom utvrđivanja povezanosti između nezavisnih varijabli i skupnih zavisnih varijabli (tablica 1) utvrđeno je da je nezavisna varijabla završna ocjena zadnjeg semestra iz MLK statistički značajno i pozitivno povezana sa skupnim varijablama nastavno posredovanje i praćenjem $i$ ocjenjivanjem studenata.

Rezultati korelacija koje su provedene na deset pojedinačnih varijabli vezanih uz skupnu varijablu nastavno posredovanje i nezavisne varijable završna ocjena (tablica 2) utvrđena je slabija, ali statistički značajna pozitivna povezanost na osam od deset tvrdnji. Dobiveni rezultati ističu važnost nastavnika i njegova odnosa sa studentima te način vođenja nastave, mogli bismo reći kvalitetu odnosa koji nastavnik svojim radom uspostavlja sa studentom. Ako je student zadovoljan radom nastavnika, načinom izvođenja nastave, aktivnog uključivanja u nastavni proces, suradničkim odnosom, navedeno će biti pozitivno povezano i sa završnom ocjenom jer će motivirati studente da se bolje pripreme za završni ispit, odnosno pobuditi interes za predmet MLK. Mnogi autori ističu važnost suradničkih odnosa nastavnika sa studentima te vođenje nastave usmjerene na poticanje studenata na aktivno sudjelovanje u nastavi. ${ }^{18}$

Osim pozitivne povezanosti nastavnog posredovanja sa završnom ocjenom na temelju dobivenih rezultata, izdvaja se i praćenje i ocjenjivanje studenata. To pokazuje da u utvrđivanju povezanosti zadovoljstva studenata nastavnim predmetom MLK sa završnom ocjenom, osim izdvojenoga nastavnog posredovanja, značenje imaju i jasni kriteriji ocjenjivanja i vrednovanja postignuća.

Detaljnijom analizom korelacije između nezavisnih varijabli i pojedinačnih varijabli (tvrdnji) vezanih uz praćenje $i$ ocjenjivanje studenta na gotovo svim tvrdnjama uočena je statistički značajna pozitivna povezanost između završne ocjene i tvrdnji vezanih uz praćenje $i$ ocjenjivanje, dok kod ostalih nezavisnih varijabli nije bilo statistički značajnih korelacija (tablica 3 ).

Iz toga je razvidno da je studentima praćenje i ocjenjivanje njihova rada važno te tvrdnje poput objektivnosti ocjenjivanja od strane nastavnika, mogućnosti da student ima priliku (pr)ocijeniti sebe i druge, da na vrijeme dobiva povratnu informaciju o svom radu te da su te nastavnikove povratne informa-

\footnotetext{
${ }^{18}$ Ladislav BOGNAR, Suradničko učenje u sveučilišnoj nastavi, Život i škola, 52 (2006) 15-16, 7-16; Chris Kyriacou, nav. dj., 127; Hilbert MEYER, Što je dobra nastava, Zagreb, Erudita, 190.
} 
cije konkretne i jasne - prema mišljenju studenata pozitivno djeluju na samu završnu ocjenu. Dosadašnja su istraživanja pokazala da zadovoljstvo studenata nastavom može biti povezano s jasnoćom kriterija ocjenjivanja i vrednovanja postignuća studenata, odnosno da je zadovoljstvo nastavom veće što je praćenje i ocjenjivanje objektivnije i transparentnije. ${ }^{19}$

Kao jedna od obaveza studenata, osim polaganja završnog ispita, je i redovito pohađanje nastave. Stoga smo nastojali istražiti povezanost zadovoljstva studenata nastavnim predmetom MLK s brojem izostanaka. Ispitivanjem povezanosti između nezavisne varijable broja izostanka s nastave MLK i skupnih varijabli, uočena je statistički značajna negativna povezanost sa skupnom varijablom nastavno posredovanje (tablica 1). To bi se moglo interpretirati kao pojavnost ako nastavnik nije osigurao kvalitetnu nastavu, povećat će se broj izostanaka s nastave jer studenti nisu motivirani za redovito pohađanje nastave. Ispitivanjem korelacije između broja izostanaka s nastave MLK i pojedinačnih varijabli unutar skupne varijable nastavno posredovanje statistički značajni dobiveni koeficijenti korelacije bili su negativno povezani s polovicom pojedinačnih varijabli (tablica 2). To znači da smanjeno zadovoljstvo studenata nastavnim posredovanjem, odnosno odnosom s nastavnikom koje se ogleda $\mathrm{u}$ jasnoći izlaganja i objašnjavanja sadržaja predmeta MLK, jasnoći ishoda nastavnog predmeta MLK, zanimljivosti sadržaja nastavnih predavanja iz MLK, utječe i na rado polaženje nastavnog predmeta MLK, odnosno možemo reći da negativno utječe na broj izostanaka s nastave. Burns i Ludlow u svom su istraživanju dokazali da je manji broj izostanaka s nastave povezan $\mathrm{s}$ većim zadovoljstvom studenata. ${ }^{20}$ Izostanci s nastave mogu biti odraz karakteristika studenata koje su oni posjedovali i prije upisa na studij, međutim mnoga istraživanja potvrđuju činjenicu važnosti uloge nastavnika jer upravo odabirom primjerenih nastavnih metoda nastavnici mogu aktivno uključiti studente $u$ nastavu čime će i njihovo zadovoljstvo nastavom biti veće, a izostanci s nastave manji. ${ }^{21}$

S obzirom na cilj istraživanja, postavili smo i problem kojim smo željeli istražiti povezanost zadovoljstva studenata nastavnim predmetom MLK s nekim aspektima organizacije nastave, a u kontekstu ovog istraživanja mjeri se brojem studenata na predavanjima i metodičkim vježbama iz MLK.

Pri propitivanju povezanosti između nezavisnih varijabli i skupnih varijabli uočeno je da je nezavisna varijabla broj studenata na predavanjima iz MLK pozitivno povezana sa skupnom varijablom nastavno posredovanje (tablica 1). Usporedbom povezanosti nezavisne varijable broj studenata na predavanjima s pojedinačnim tvrdnjama skupne varijable nastavno posredovanje uočena je statistički značajna pozitivna povezanost s tri tvrdnje koje se odnose na jasno-

\footnotetext{
${ }^{19}$ Vranešević, Mandić, Horvat, nav. dj., 83-92.

${ }^{20}$ Burns, Ludlow, nav. dj., 127-138.

${ }^{21}$ López-Pérez, Pérez-López, Rodriguez-Ariza, nav. dj., 818-826.
} 
ću nastavnikova izlaganja i objašnjavanja sadržaja predmeta MLK, zatim na zanimljivost sadržaja nastavnih predavanja i s tvrdnjom rado polaženje nastavnog predmeta $M L K$ (tablica 2).

Prema dobivenim povezanostima može se reći: ako je sadržaj predmeta studentima izlagan jasno i zanimljivo, to će biti pozitivno povezano s većim odazivom studenata na predavanjima. To ističe činjenicu da, ako su studenti zadovoljni načinom izlaganja, jasnoćom sadržaja koji nastavnik predaje, bit će zainteresirani i motivirani za rado polaženje nastave iz MLK. Navedeno potvrđuje i istraživanje koje su proveli Burns i Ludlow u kojem je veće zadovoljstvo studenata nastavom povezano s manjim brojem izostanaka, ali i radom $\mathrm{u}$ manjim skupinama. ${ }^{22} \mathrm{U}$ nastavi MLK rad u manjim skupinama izvodi se na vježbama. Ispitivanjem povezanosti između nezavisne varijable broj studenata na vježbama iz $M L K$ i skupnih varijabli najviše je povezanosti uočeno s metodičkim posredovanjem u vrtiću, organizacijom nastave $i$ kompetencijama studenata (tablica 1).

Studenti su obavezni prisustvovati svim metodičkim vježbama budući da im upravo taj oblik nastave pruža mogućnost partnerstva sa sveučilišnim nastavnikom i ostalim studentima, pritom nastavnik i mentor u vrtiću individualno prate i provode analizu studentova rada s djecom, a studenti imaju slobodu provedbe likovnih aktivnosti s djecom prema svojoj ideji.

Povezanost između nezavisne varijable broj studenata na vježbama iz MLK i tvrdnji vezanih uz skupnu varijablu organizacija nastave $M L K$ statistički je značajno i pozitivno dokazana s tri od pet pojedinačnih varijabli (tablica 5) te iz dobivenih rezultata možemo zaključiti da je očekivano da će broj studenata na vježbama iz $M L K$ biti pozitivno povezan s usklađenošću rasporeda nastave na fakultetu i rasporeda metodičkih vježbi te s pravovremenim i jasnim priopćavanjem promjena u rasporedu. Usklađen raspored jedna je od ključnih stavki svake organizacije nastave te utječe na zadovoljstvo studenata nastavom.

Ujedno možemo reći da prisustvovanje studenata nastavi iz metodičkih vježbi iz MLK pozitivno djeluje na poticanje i razvoj njihovih socijalnih kompetencija, koje $\mathrm{u}$ ovom kontekstu podrazumijevaju uspostavu kvalitetna odnosa s djecom, mentorom odgajateljem, sveučilišnim nastavnikom (tablica 6). Čak i pasivno prisustvovanje nastavi, primjerice na predavanjima, može pozitivno odraziti na kompetencije studenata i njihove završne ocjene. ${ }^{23}$

\footnotetext{
${ }^{22}$ Burns, Ludlow, nav. dj., 127-138.

${ }^{23}$ Usp. Credé, Roch, Kieszczynka, nav. dj., 272-295.
} 


\section{Zaključak}

U ovom istraživanju cilj je bio utvrditi povezanost zadovoljstva studenata Ranog i predškolskog odgoja i obrazovanja nastavom MLK na učiteljskim fakultetima u Republici Hrvatskoj s nekim aspektima organizacije nastave te obvezama studenata. Pritom su za ovo istraživanje izdvojeni neki aspekti organizacije nastave koji se odnose na broj studenata na predavanjima i vježbama, a obveze studenata mjere se brojem izostanaka i njihovim završnim ocjenama. Završna ocjena zadnjeg semestra iz MLK je značajno pozitivno povezana sa zadovoljstvom studenata glede nastavnog posredovanja te praćenja i ocjenjivanja studenata, a broj izostanaka s nastave značajno je negativno povezan sa zadovoljstvom studenata s nastavnim posredovanjem. Takvi su rezultati istraživanja očekivani jer zadovoljstvo radom nastavnika, kvalitetom izvedbe nastave, objektivnošću ocjenjivanja, dobivenim povratnim informacijama te odnosima studenata i nastavnika može motivirati studente da aktivno sudjeluju u nastavi i da se bolje pripreme za završni ispit. Ako studenti nisu zadovoljni kvalitetom nastavnog posredovanja, veća je i vjerojatnost da neće redovito pohađati predavanja, što bi objasnilo i negativnu povezanost broja izostanaka sa zadovoljstvom studenata nastavnim posredovanjem.

Broj studenata na predavanjima bio je značajno pozitivno povezan s nastavnim posredovanjem, a broj studenata na vježbama iz MLK bio je značajno pozitivno povezan s metodičkim posredovanjem u vrtiću, organizacijom nastave MLK i kompetencijama studenata. Iako je istaknuto da veći broj studenata na predavanjima umanjuje vjerojatnost razvoja suradničkih odnosa između studenata i nastavnika, moguće je da više studenata redovito pohađa predavanja kada su zadovoljni nastavom i nastavnikom. U kontekstu samog nastavnog predmeta MLK velik dio nastave izvodi se metodičkim vježbama u manjim skupinama, što pozitivno djeluje na zadovoljstvo jer je u tom slučaju interakcija i komunikacija s nastavnikom puno veća, studenti su aktivni i mogu izraziti svoje ideje i kreativnost, što ujedno pozitivno djeluje i na razvoj kompetencija.

S obzirom na visinu koeficijenata korelacije (niske vrijednosti) nisu omogućena skupna predviđanja te treba biti oprezan s generalizacijama. Budući da je riječ o kategoriji velikog uzorka to djeluje na razinu statističke značajnosti. 


\section{Marijana Županić Benić*}

Connection between the satisfaction with art methodology teaching and some aspects of students' obligations and organisation of teaching

\section{Summary}

The paper deals with the connection between the satisfaction with Art Methodology Teaching (AMT) and the organisation of teaching and students' obligations. Only some of the aspects of the organisation of teaching were singled out, which in the context of this research imply the number of students at lectures and exercises, while students' obligations regarding the study were measured by the number of absences and their final grades. The research was carried out at seven Faculties of Teacher Education in the Republic of Croatia, at the sample of 220 third year students of Early childhood and preschool education. Correlations were carried out between independent variables final grade, number of absences, number of students at AMT lectures and exercises and statements connected with group dependent variables, among which they are in a statistically significant correlation: teaching mediation, monitoring and evaluation of students and the organisation of Art Methodology teaching. The satisfaction of students with Art Methodology Teaching in this research has been mostly expressed through correlations of independent variables with the teaching mediation which implies quality teaching process and collaborative relationship teacher-students. Like in previous studies, both students' satisfaction and smaller absenteeism were connected with the work in smaller groups. Key words: satisfaction with teaching, Art Methodology, students' obligations, organisation of teaching.

(na engl. prev. Evelina Miščin)

\footnotetext{
* Marijana Županić Benić, PhD, lecturer at Faculty of Teacher Education, University in Zagreb; Address: Savska c. 77, HR-Zagreb, Croatia; E-mail: marijana.zbenic@ufzg.hr.
} 